\title{
DESIGN METHODOLOGIES FOR STEEL STRUCTURES IN SEISMIC REGIONS
}

\author{
Rohit Kumar Rajora $^{1^{*}}$, Rishabh Lamba ${ }^{2}$, Vishal Chaudhary ${ }^{3}$, Rohit Ashish Dhyani ${ }^{4}$
}

\section{*Corresponding Author: -}

\section{OUTLINE}

1. Introduction

2. New Methodologies.

3. Moment Resisting Frames and Elastic Flexibility

4. Eccentrically Braced Frames and Ductility

5. Design guidelines

6. Factors to consider

7. Conclusions.

8. References

\begin{abstract}
: -
This paper is an insight into the recent developments in the design methodologies in seismic design of steel structures. Recent damage throughout the world due to earthquakes have led to the conclusion that the inherent seismic resistance of steel Structures should not be taken for granted. Due to increasing number calamities occurring due to earthquakes per year, new advancements have to be made in the design procedures and material control measures as well as welding practice. We will look into the solutions such as displacement-based design and Assessment procedures alongside the generalization of limit state concepts into a performance-based Design framework. In this paper, recent findings on the material, section, member and sub assemblage Levels are reviewed and possible code applications are highlighted. However, our main concern will be moderate seismic zones.
\end{abstract}

Keywords: - earth quake hazards, new methodologies, moment frames, research. 


\section{INTRODUCTION}

All the building codes available throughout the world has given very little significance to the seismic coefficient of a terrain it could be said they have demeaned the earthquake hazard. This sudden impact of seismic design and detailing requirements on moderate seismic regions has revealed a serious concern: the structural engineering community has not developed and articulated a rational seismic design philosophy for moderate seismic regions. As a result, engineers in moderate seismic regions are compelled by law to design structures according to prescriptive requirements that are untested. These untested requirements can lead engineersto designs that are both unsafe and unnecessarily expensive. The paper discusses structural systems: Moderate-Ductility Concentrically-Braced Frame (CBF), Dual Systems, which employ reserve capacity; Moment-Resisting Frames (MRFs), which employ elastic flexibility; and Eccentrically-Braced Frames (EBFs), which employ ductility and capacity design. The paper discusses the role that strength plays in each of these concepts and its relationship to design for wind loads. In conclusion, the paper outlines the need for future research related to the continued development and validation of this philosophy.

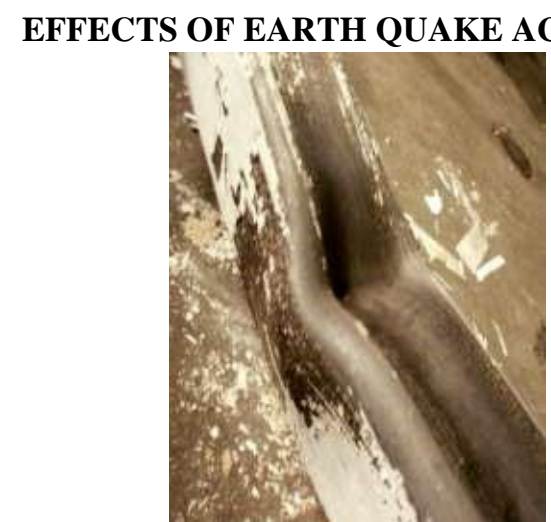

1.Local strain concentration

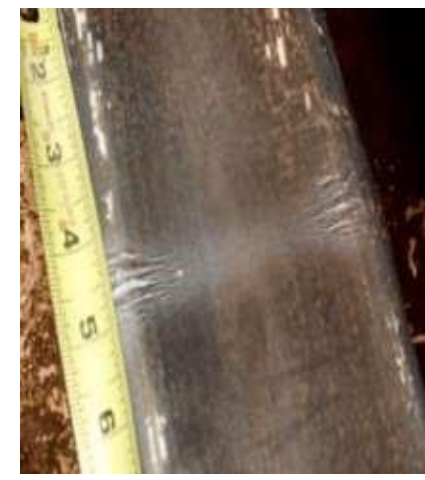

2. Initiation of tearing

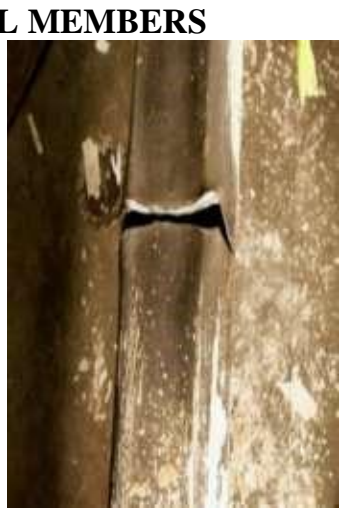

3. fracture

\section{New Methodologies}

*Moderate ductility dual system

Many buildings currently designed using a response modification coefficient, $R$, equal to 3 , which allows seismic detailing to be ignored. This approach has not been proven to guarantee acceptable seismic performance. Furthermore, using $R=3$ can result in design forces in the building and its foundations that are higher than forces resulting from wind loads, thereby increasing cost without clearly achieving elevated performance. This paper on the other hand introduces a dual system for Seismic Design Categories A, B and C that allows $\mathrm{R}=5$ when a stiff primary system is combined with a flexible moment frame reserve system to Form a moderate ductility dual system.

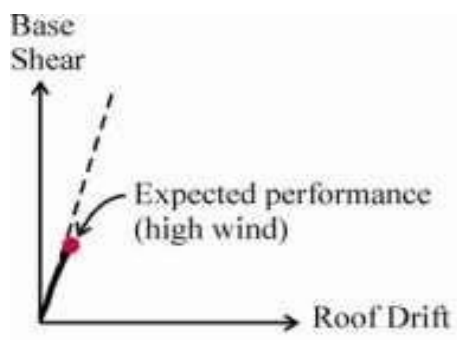

(a) Low seismic

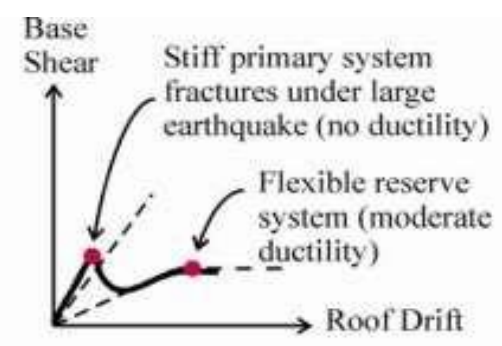

(b) Moderate seismic

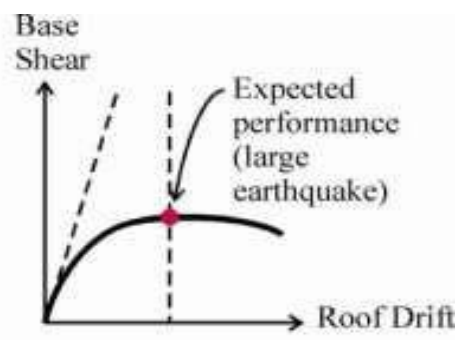

(c) High seismic

Above figure shows the context for the moderate-ductility dual system, where it is contrasted with low seismic (wind) design that requires very little system ductility and high seismic design that requires large system ductility. In the case of high seismic design, the system ductility is Achieved through large component ductility, e.g., plastic hinges, brace buckling or brace yielding. In contrast, the different stiffness's of the braced and moment frames in the moderate ductility dual system provide system ductility without requiring component ductility.

\section{Moment Resisting Frames and Elastic Flexibility}

The moment resisting frames are used in order to adapt reliability-based performance assessment procedures for use ith low-ductility systems in moderate seismic regions, it is necessary to estimate theeffects of connection capacity on ystem collapse capacity. Furthermore, because the systemsresponded in nearly equal measure in the first three modes The lack of connection ductility plays less of a role, as only one of the 14 ground motions in the suite causes strength degradation in the panelZone model. Similar performance assessments of a stiffer $R=3$ chevron CBF reveals that as the stiff system attracts higher forces, the low-ductility characteristics of the braced frame became more critical to overall performance. For such a stiff, low-ductility system, the reserve capacity provided by the gravity framing becomes the primary collapse prevention mechanism (Hines et al. 2009). Since the braced frame is controlled by strength considerations, and ismuch 
stiffer than necessary to meet the elastic story drift criterion (in this case $h / 400$ ) that controlled the moment frame proportions, the braced frame attracted more force than the momentframe under the same design event. Although variability in projectspecific drift limits and the inherent flexibility of moment frames should be carefully considered alongside strength and ductility.

\section{Eccentrically Braced Frames and Ductility}

Wind base shear is compared to seismic base shear for Three cases:

1. $R=3 \mathrm{CBF}$ where the seismic base shear is determined using the approximate Fundamental period, $\mathrm{Ta}$.

2. $R=3 \mathrm{CBF}$ where the seismic base shear is determined using the upper limit on calculated Period, where $T a$ is multiplied by a coefficient, $\mathrm{Cu}$, equal to 1.7 in this case.

3. $R=7 \mathrm{EBF}$ where the seismic base shear is determined using $T=C u t=1.7 T a$.

The $R=3 \mathrm{CBF}$ base shears are shown for $T \mathrm{a}$ and $\mathrm{Cu} t$ since the simpler approach $(\mathrm{Ta})$. Designers generally use the second approach in order to reduce steel tonnage. Lower forces reduce member sizes and the $R=3$ provision excuses the structure from any special detailing requirements. Fig. 3 shows that under the MSBC 7th Edition the motivation to pursue seismic detailing, represented by the $R=7 \mathrm{EBF}$, is not strong.

Recent research indicates that $R=3$ buildings under $100 \mathrm{ft}$. high appear to be more vulnerable to collapse than taller buildings (Hines et al. 2009). Wind is now considered even more dominant in the design of structural members but still insists that structures be detailed for a minimum level of ductile capacity. This technique is considered as a breakthrough in the modern world of steel structures.

\section{Design guidelines}

The three basic steel special moment frame design componentsare beams, columns, and beam-column connections. Beams span the horizontal clear distance between protected zones; columns span the vertical clear distance between panel zones; and the beam-column connections encompass both protected and panel zone regions at the beam-column intersections.

\section{Factors to consider-}

1. Beam strength.

2. Column splices specifications.

3. Column bases.

4. Column beam-moment ratio.

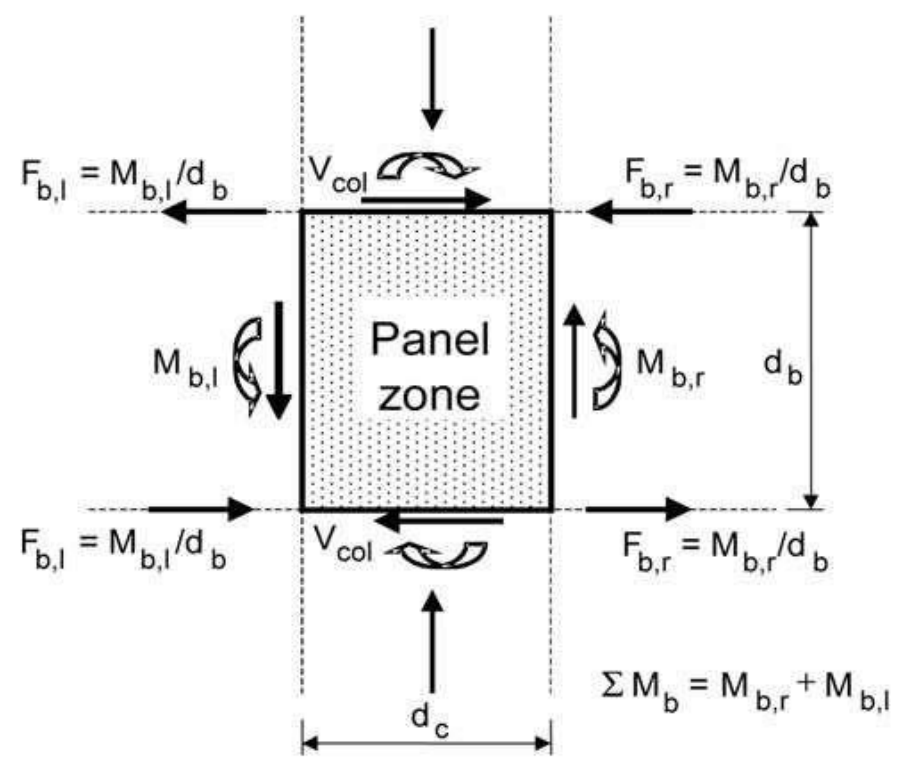

At this intersection, the ratio $\mathrm{M} P * / \mathrm{M} P^{*}$ should be greater than 1.0 , where $\mathrm{M} P^{*}$ is the sum of the plastic Moment capacities of the columns above and below the panel zone, reduced for axial load effects, and $\mathrm{M} P^{*}$ is the sum of beam moments obtained by "projecting" the expected flexural strengths of the beams from the plastic hinge locations to the column centerline.

5. Continuity plates- they should be used to impart strength.

6. Beam to web connection should be strictly made according to the code. 


\section{Conclusions-}

This paper at large gives a view on possibility of transforming seismic steel design in moderate seismic Regions through the development of innovative structural configurations based on a new design Philosophy. Elements of this discussion have the potential to broaden the impact of earthquake Engineering approaches that are common in high seismic regions. A consistent design Philosophy for moderate seismic regions has the potential to save lives, conserve resources And Enhance creativity in design. As it continues to develop, this new design philosophy must berigorously grounded in hazard assessment and ground motion development that capture theunique aspects of geology and seismicity found in moderate seismic regions. Numerical and Large-scale experimental simulations must be used to evaluate the relationships between strength, Ductility and reserve capacity in steel-framed buildings and must lead to reliable performance and collapse prevention.

\section{References}

[1].ACI (2008). Building code requirements for structural concrete (ACI 318-08) and commentary, American Concrete Institute, Farmington Hills, MI.

[2].AISC (2006). Seismic design manual, American Institute of Steel Construction, Inc., Chicago, IL.

[3].AISC (2005a), ANSI/AISC 341-05. Seismic provisions for structural steel buildings, American Institute of Steel Construction, Inc., Chicago, IL.

[4].AISC (2005b), ANSI/AISC 358-05. Prequalified connections for special and intermediate steel moment frames for seismic Applications including Supplement No. 1, American Institute of Steel Construction, Inc., Chicago, IL.

[5].AISC (2005c), ANSI/AISC 360-05. Specification for structural steel buildings, American Institute of Steel Construction, Inc., Chicago, IL.

[6].AISC (2005d), AISC 303-05. Code of standard practice for steel buildings and bridges, American Institute of Steel Construction, Inc., Chicago, IL.

[7].ASCE (2006). Minimum design loads for buildings and other structures (ASCE/SEI 7-05) including Supplement No.2, American Society of Civil Engineers, Reston, V

[8].AISC, 1992, 1997, 2002, 2005. Seismic Provisions for Structural Steel Buildings, American Institute of Steel Construction, Chicago, Illinois.

[9].ASCE, 1988, 2002, 2005. Minimum Design Loads for Buildings and Other Structures, American Society Of Civil Engineers, New York, New York, and Reston, Virginia.

[10]. AIJ [1995] Preliminary Reconnaissance Report of the 1995 Hyogoken-Nanbu Earthquake, Architectural Institute of Japan, April, 216 pp.

[11]. American Iron and Steel Institute [1991] Performance of steel buildings in past earthquakes, AISI, 97 pp. Bernuzzi, C., Zandonini, R. and Zanon, P. [1991] "Rotational behaviour of end plate connections," Costruzioni Metalliche, no. 2, pp. 74-103.

[12]. Bernuzzi, C., Zandonini, R. and Zanon, P. [1992] "Semi-rigid steel connections under cyclic loads," Proceedings of the First World Conference of Constructional Steel Design, Acapulco, Mexico, pp. 375-384. Bouwkamp, J. and Paring, H. [1998] "Evaluation of behaviour factors for moment resisting frames based on the Ispra tests," ICONS Topic 4 report, Madrid, May.

[13]. Broderick, B.M. and Elnashai, A.S. [1994] "Seismic resistance of composite beam-columns in multi-storey structures, Part II: Analytical model and discussion of results," Journal of Constructional Steel Research, Vol. 30, pp.231-258.

[14]. Broderick, B.M., Elnashai, A.S., Ambraseys, N.N., Barr, J., Goodfellow, R. and Higazy, M. [1994] "The Northridge (California) earthquake of 17 October 1994; observations, strong-motion and correlative response analyses," Engineering Seismology and Earthquake Engineering Report No. ESEE 4/94. Farmington Hills, MI.

[15]. AIJ (1995). Preliminary reconnaissance report of the 1995 Hyogo-ken Nanbu Earthquake, (English Edition) Architectural Institute of Japan, Tokyo, p. 216.

[16]. AISC (1997). Seismic provisions for structural steel buildings, American Institute of Steel Construction, Chicago, IL.

[17]. AISC (2010a). Seismic provisions for structural steel buildings (AISC 341-10) and commentary, American Institute of Steel Construction, Chicago, IL.

[18]. AISC (2010b). Specification for structural steel buildings (AISC 360-10) and commentary, American Institute of Steel Construction, Chicago, IL.

[19]. AISC (2012). Seismic design manual, American Institute of Steel Construction, Chicago, IL. ASCE (2010). Minimum design loads for buildings and other structures (ASCE/SEI 7-10), American Society of Civil Engineers, Reston, VA. 